\title{
The Use of Social Media and Social Media Marketing Tools by the Polish Marshal Offices to Promote Health
}

\author{
Magdalena Syrkiewicz-Świtała, Katarzyna Lar, Tomasz Holecki \\ Medical University of Silesia, Katowice, Poland
}

\begin{abstract}
The increasing number of people using social media determines the contemporary approach to the means of communication to the information society. The Marshal Offices willing to conduct effective health promotion campaigns are forced to adapt to the changing trends in the modern marketing communication. The aim of this study is to determine whether the Polish Marshal Offices use the tools of social media marketing activities in the field of health promotion. Fourteen Marshal Offices in Poland were investigated. Two methods of research were used: CAWI and CATI based on author's questionnaire. Data analysis was based on standard statistical methods. Results show that $93 \%$ of responding offices are involved in activities related to the promotion of health. The main domains are: cancer (30\%) and stimulants (28\%). In the opinion of employees of the Marshal Offices, the most convincing form of communication with patients is direct promotion (46\%). Far less important are information posters $(12 \%)$ or TV spots (10\%); $56 \%$ of offices do not use social networking sites in the conduct of health campaigns. The other commonly used canals in these operations are Facebook (25\%) or YouTube (6\%); $50 \%$ of offices do not apply the tools of social media marketing. The rest declare active participation in discussions on Internet health forums. The main conclusion is that it has been postulated to pay more attention to social media and social media marketing tools in health promotion campaigns carried out in order to improve the efficiency of communication with the present information society.
\end{abstract}

Keywords: marketing communication, social media, social media marketing, health promotion

\section{Introduction}

Nowadays, due to the latest technology, it observed a dynamic development of communication based on the medium of the Internet. The network has not only become a popular medium, but also an effective, efficient, and accessible communication channel. The Internet allows two-way communication in which the recipient and the sender can take their roles. In addition, the network makes it possible to use it for a lot of people at the same time (Pabian, 2008a). It is observed in this medium that fast and uninhibited transfer is necessary and important content from the point of view of its users. The ties between Internet users are formed around the concerns of

Magdalena Syrkiewicz-Świtała, Ph.D., Department of Health Economics and Health Management, School of Public Health in Bytom, Medical University of Silesia, Katowice, Poland.

Katarzyna Lar, M.Sc., Department of Health Economics and Health Management, School of Public Health in Bytom, Medical University of Silesia, Katowice, Poland.

Tomasz Holecki, Ph.D., Department of Health Economics and Health Management, School of Public Health in Bytom, Medical University of Silesia, Katowice, Poland.

Correspondence concerning this article should be addressed to Magdalena Syrkiewicz-Świtała, Department of Health Economics and Health Management, School of Public Health in Bytom, Medical University of Silesia, Katowice, Poland. 
their subjects, content, products, services, or issues including health (Syrkiewicz-Świtała \& Świtała, 2012). The individuals associated in the net make relationship building social media. The persons co-create content and exchange opinions in a fast and dynamic way. Efficient flow of information in social media is also facilitated by the development of mobile digital devices which undoubtedly support the rapid dissemination of specific information. Virtual and mobile technologies also allow a significant reduction in communication costs (Pabian, 2008b).

The increased interest in social media in the society has allowed for the creation of a new Internet marketing tool (Dryl, 2011). In particular, it is important to pay attention to the tools of social media marketing, whose essence may be described as "a set of relationships, behaviours, feelings, empiricism and the interaction between consumers, and brands, where is the multidirectional communication exchange of experience with advanced communication tools" (Trzeciak, 2009). Currently, the importance of social media takes on more and more comprehensive. They serve not only to build social relationships, but they have become the basis for the search for information on specific products or services. In social media, the marketing activities are carried out to strengthen the business messages (Dorenda-Zaborowicz, 2012). Contents apply to both developed specific products and services, but also ideas aimed at creating new social attitudes and beliefs (Andreasen, 2002). It may be a field for work in health promotion and education. Through the concept of health promotion, it is understood "the process of enabling every human being to increase the impact on their health in terms of the improvement and maintenance" (Karski, 1992, pp. 20-22). As a result, it is understood as the creation of the conditions necessary to be informed to improve the health of the population. It is to ensure adequate access to necessary health-promoting behaviour that promotes knowledge and supports social responsibility for health. It also seeks to put pressure and increase the impact on health in local and regional communities, i.e. in the state institutions (Czupryna, Poździoch, Ryś, \& Włodarczyk, 2001). Via the Internet and in the social media, using the tools of social media marketing, message senders can monitor the behaviour of recipients and track and create their opinions in the area of health.

The evolution of electronic media and rapid development of mobile communication affect the nature of the functioning of individuals, households, communities, and state institutions (Gani \& Clemens, 2006). Modern communication and information technologies that enter the market led to improvement of the communication process. The communication becomes faster, less expensive, and flexible. It adapts to changing market conditions and the expectations of demanding clients/patients (Kulka, 2014). Today's message recipients have much greater access to information and the freedom to choose the media (Syrkiewicz-Świtała, Holecki, \& Wojtynek, 2014). The recipients seek content on health. It is a new area for communication in the health promotion. Clients/patients seek communication channels and sources that are inexpensive and available at any time of the day. The channels must be adapted to the rhythm of modern life. Recipients of messages in the field of health promotion are becoming more demanding. They want to receive information in ways that are the most convenient, accessible, and tailored to their needs. It naturally forces the authors of these messages to provide more innovation in the preparation of content (Vilaseca-Requena, Torrent-Sellens, \& Jimenez-Zarco, 2007). The Internet gives the possibility of easier and cheaper collection of information about a health problem. This is especially important for patients within a group of people born in new technologies era (e.g. Generation Y-year of birth 1980-1995 (Gordon, 2014). The use of the Internet and social media in health-oriented communication is essential forms of communication for those young people and becomes a prerequisite for effective communication (Syrkiewicz-Świtała, 2014). 
The social media create therefore space for an efficient and modern way of communicating with the target groups for the promotion of health (Evans, 2006). They are able to respond to undesirable social phenomena and test new activities in the field of health promotion and health education (Syrkiewicz-Świtała, Holecki, Sobczyk, Wróblewski, \& Lar, 2015). In the digital era, it seems to be a perfect idea of social media connection with the tasks related to the promotion and health education undertaken by state institutions. It has become a prerequisite to choose topic of this paper. The goal was to investigate whether the Marshal Offices use social media marketing and social media tools to communicate with the environment in the field of health promotion.

\section{Research Objectives}

The main objective of the study was to determine whether, in the era of ubiquitous Internet, Polish Marshal Offices use Internet marketing tools, with particular emphasis on social media marketing activities in the field of health promotion. Specific objectives of the study focus on the activities of Polish Marshal Offices in the field of health promotion and use of social media marketing tools:

- Identification of areas of activity of Polish Marshal Offices in the field of health promotion.

- Identification of marketing communication tools used by Polish Marshals Offices in activities in the field of health promotion.

- Determination whether and how the Polish Marshal Offices use the tools of social media marketing for their actions in the field of health promotion.

- Formulation of postulates of recommendations to improve the communication efficiency by Polish Marshal Offices in the field of health promotion.

\section{Material and Methods}

The research material was collected using an online survey (CAWI-Computer-Assisted Web Interview) and telephone interviews (CATI-Computer Assisted Telephone Interview). Obtaining statistical data followed in several steps. Invitation to participate in the study was sent by e-mail. The invitation consisted of a covering letter, information about the project implemented, and a hyperlink to the questionnaire (CAWI). At intervals of several days, three mailings were made. In order to complete the missing number of surveys, a call center studio was launched.

The study was nationwide, as all the Marshal Offices were invited to participate. Consent to participation in the project expressed 14 offices. The samples for the study were purposeful.

\section{Results}

Taking action in the field of health promotion declared 13 Marshal Offices (92.9\%). Only one tested office (7.1\%) did not engage in any activities in the area of health care. Marshal Offices' activities in the field of health promotion are shown in Figure 1.

Polish Marshal Offices prefer to engage in health promotion campaigns for the cancers $(N=14 ; 100 \%)$ and stimulants $(N=13 ; 92.9 \%)$. Also the actions to combat domestic violence are often taken $(N=7 ; 50 \%)$, cardiovascular disease $(N=5 ; 35.7 \%)$ and lung disease $(N=4 ; 28.6 \%)$. The least frequent activity in the area of health promotion carried out by Marshal Offices concerns of obesity among adults $(N=2 ; 14.3 \%)$ and children $(N=1 ; 7.1 \%)$. Figure 2 presents the topics of health promotion campaigns carried out by the Marshal Offices.

Marshal Offices most frequently implement activities in health promotion through the organization of 
conferences $(N=11 ; 26.8 \%)$. Willingly used form of activity is workshops $(N=8 ; 19.5 \%)$, as well as the initiation of television programs $(N=7 ; 18 \%)$, and finally the development of information brochures $(N=6$; $14.6 \%)$. Least likely health promotion campaigns are carried out by organizing concerts $(N=4 ; 9.8 \%)$, the development of information leaflets $(N=3 ; 7.3 \%)$, and initiating radio programs $(N=2 ; 4.9 \%)$. Methods of implementation of activities in the area of health promotion by Marshal Offices are illustrated in Figure 3.

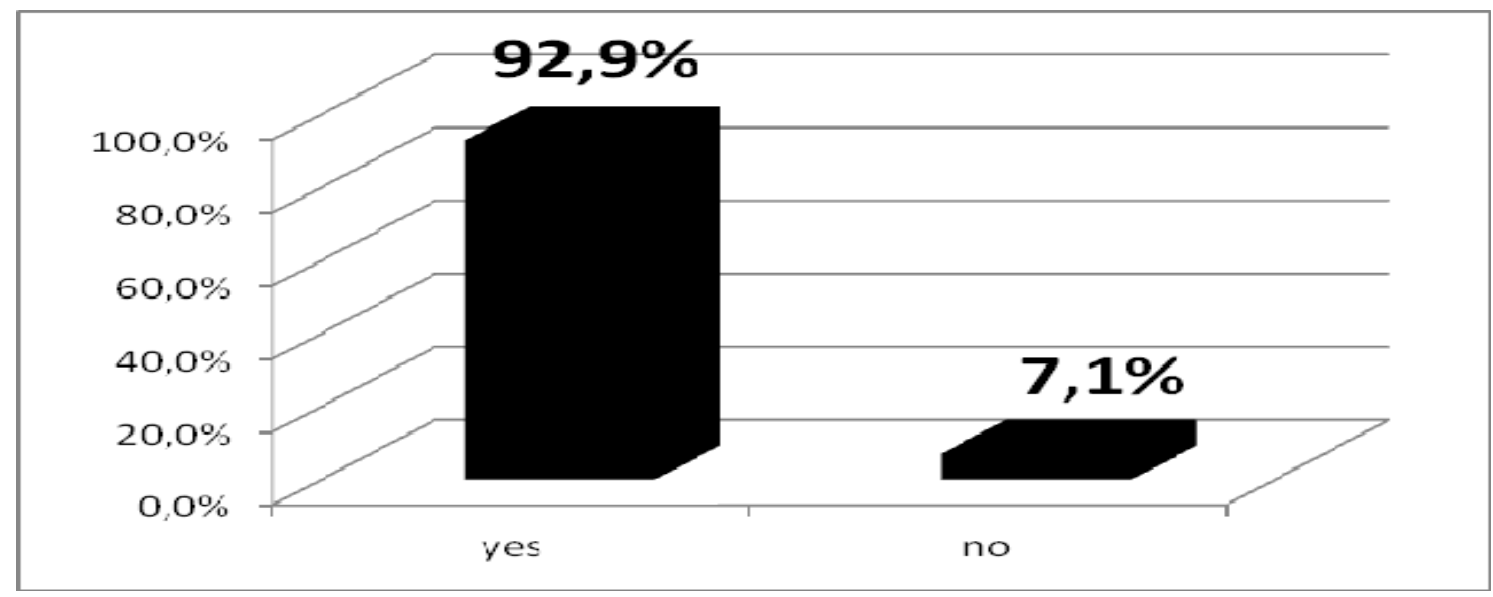

Figure 1. The involvement of Polish Marshal Offices in activities in the field of health promotion. Source: own.

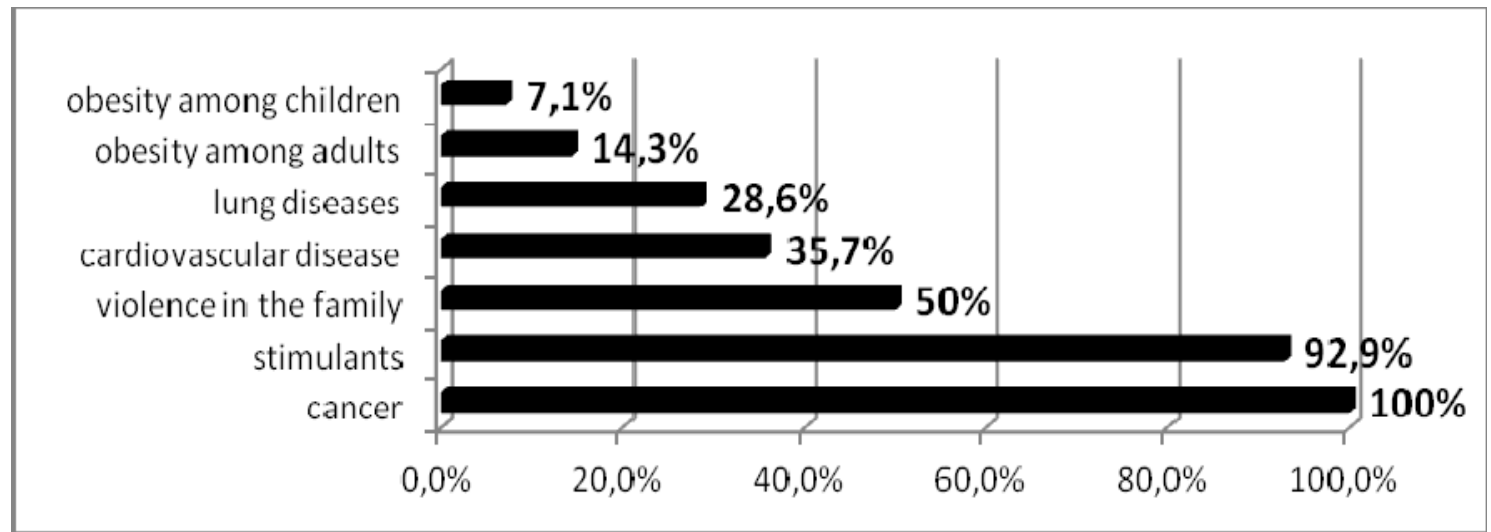

Figure 2. The health promotion campaigns carried out by the Polish Marshal Offices (results not add up to $100 \%$ - there are more possible answers). Source: own.

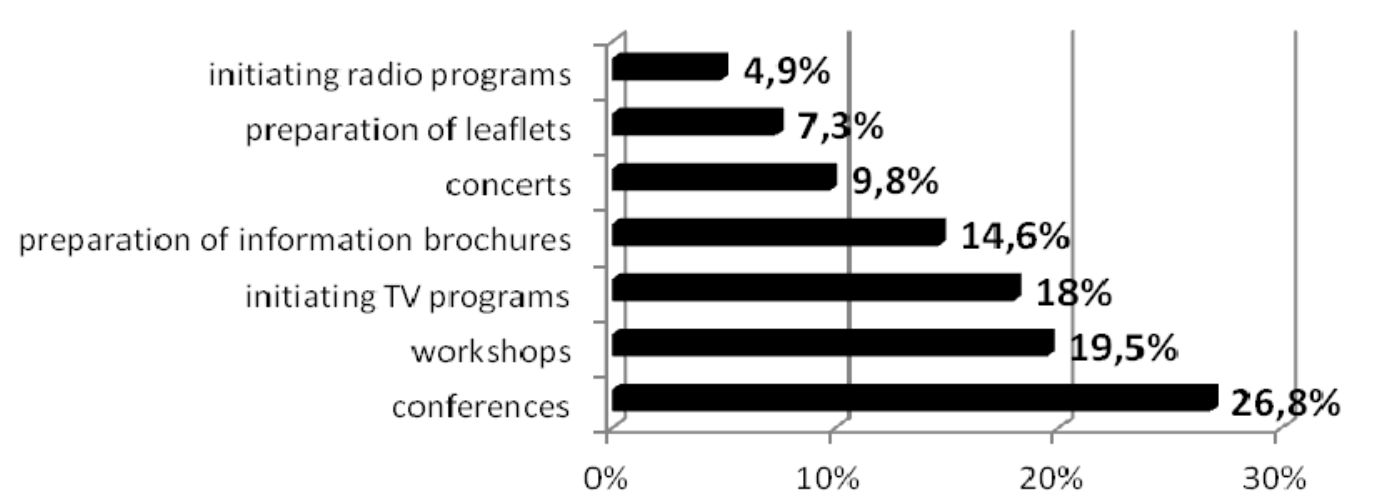

Figure 3. The means of implementation of activities in the field of health promotion by the Polish Marshal Offices (results not add up to $100 \%$ - there are more possible answers). Source: own. 
In the opinion of the staff from Marshal Offices, the most effective ways to implement activities in the field of health promotion are the organization of the conference $(N=11 ; 78.6 \%)$, workshops $(N=7 ; 50 \%)$, concerts $(N=7 ; 50 \%)$, and to initiate radio programs $(N=6 ; 42.9 \%)$. For the less effective respondents completed the development of information brochures $(N=3 ; 21.4 \%)$, initiation of television programs $(N=3$; $21.4 \%)$, and the development of leaflets $(N=2 ; 14.3 \%)$. Figure 4 illustrates the most effective ways of implementation of activities in the field of health promotion in the opinion of Marshal Offices.

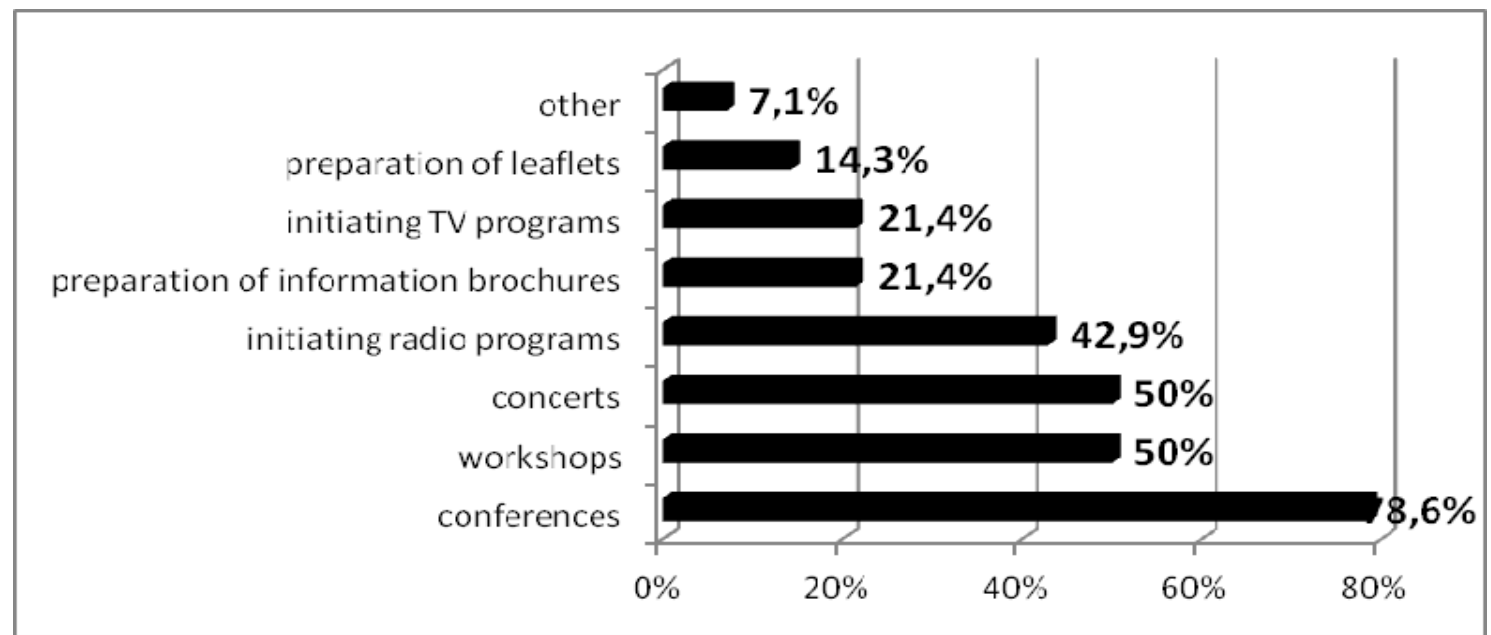

Figure 4. The most effective methods of implementation of activities in the field of health promotion in the opinion of Polish Marshal Offices (results not add up to $100 \%$ - there are more possible answers). Source: own.

Marshal Offices' cooperation with NGOs in the field of health promotion is often dedicated to drugs ( $N=$ $14 ; 100 \%)$ and cancers $(N=13 ; 92.9 \%)$. Less commonly, the third sector organizations engage in actions against domestic violence $(N=4 ; 28.6 \%)$, and the marginal importance to cooperation is the prevention of cardiovascular disease $(N=1 ; 7.1 \%)$, lung disease $(N=1 ; 7.1 \%)$, and obesity among adults $(N=1 ; 7.1 \%)$ and children $(N=1 ; 7.1 \%)$. The areas of health promotion implemented by the Marshal Office in cooperation with non-governmental organizations are illustrated in Figure 5.

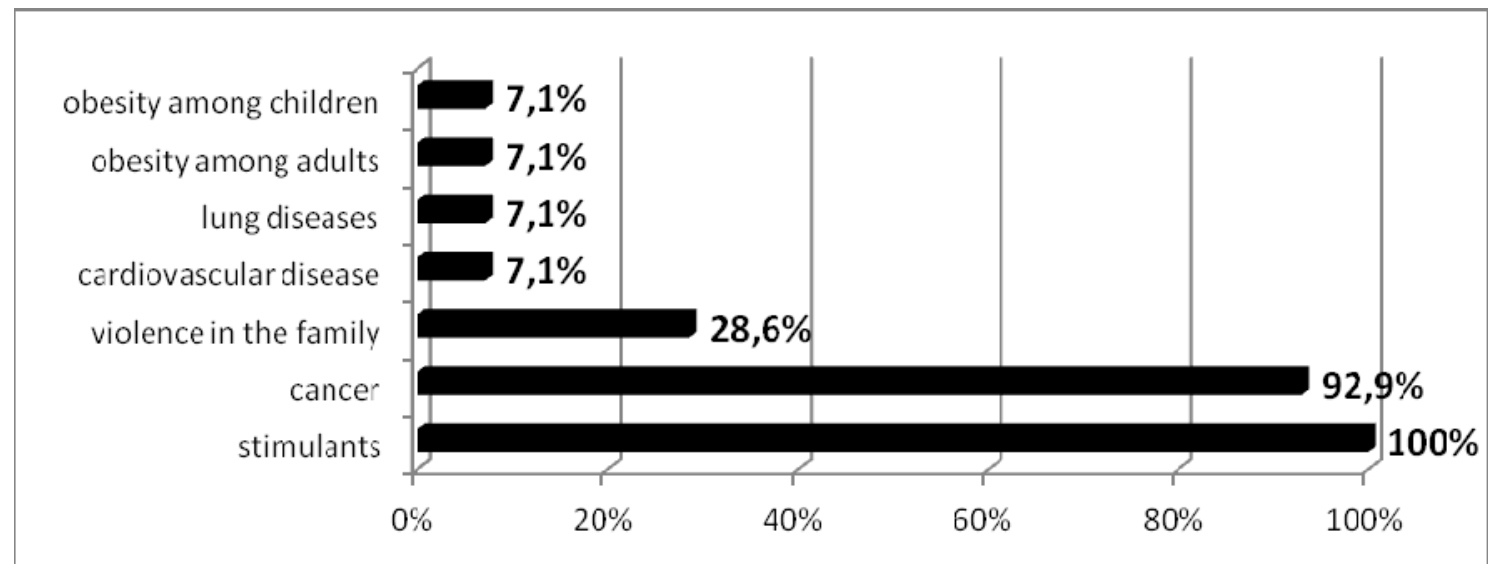

Figure 5. The areas of health promotion carried out by the Polish Marshal Office in cooperation with non-governmental organizations (results not add up to $100 \%$ - there are more possible answers). Source: own.

In the opinion of employees of Marshal Offices, the most attractive and convincing form of health promotion for patients is the direct promotion recommendations implemented by friends $(N=12 ; 85.7 \%)$. 
Effective promotion provides also doctor and pharmacist direct recommendations $(N=7 ; 50 \%)$, displaying posters in medical units $(N=6 ; 42.9 \%)$, and the issue of television spots $(N=5 ; 35.7 \%)$. Of less importance is the distribution of newsletters $(N=3 ; 21.4 \%)$ and information leaflets $(N=3 ; 21.4 \%)$, as well as direct internet promotion through recommendations from other users $(N=3 ; 21.4 \%)$. Of the least effective actions in the area of health promotion, respondents completed the street putting up billboards, posting press releases, email campaigns, and the issue of radio and online spots. Figure 6 presents the most attractive form of health promotion among patients in the opinion of Marshal Offices.

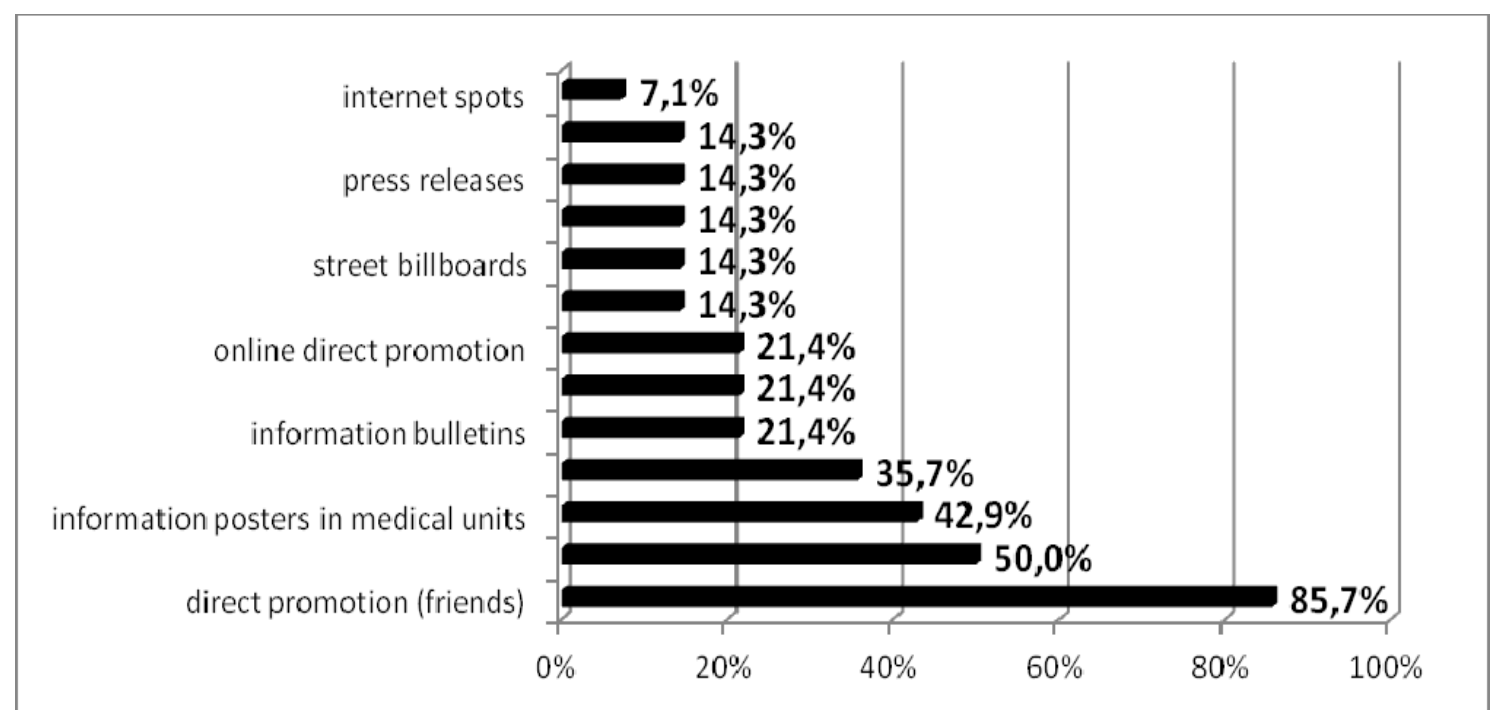

Figure 6. The most attractive form of health promotion among patients in the opinion of Polish Marshal Offices (results not add up to $100 \%$ - there are more possible answers). Source: own.

\section{Conclusions}

Almost all surveyed offices engage in activities in the field of health promotion. Activities of Polish Marshal Offices in this field consist mainly of cancer and stimulants health promotion. The organization of conferences and workshops turns out to be the most common and the most effective actions in the area of health promotion carried out by the Polish Marshal Offices. A half of the employees of Polish Marshal Offices considered direct communication of health promotion among patients to be the most convincing and inspiring confidence form. Far less important, in their opinion, is information posters and TV spots. In the opinion of surveyed offices, the direct promotion recommendations implemented by friends are the most attractive form of health promotion. More than half of the surveyed agencies, despite awareness of the importance of direct communication, do not use social networking sites in the conducting health campaigns. One quarter of responding offices used Facebook in these activities, and very few You Tube. Half of the Polish Marshal Offices do not use any social media marketing tools. The remaining half declare active participation in discussions on Internet forums on health or in moderating online forum or consulting. The study can be concluded that in the era of ubiquitous Internet less than half of the surveyed Polish Marshal Offices use social media and social media marketing tools in their efforts to promote health. It has been postulated to pay more attention by Polish Marshal Offices to social media marketing and social media tools in actions in the field of health promotion in order to improve the efficiency of communication with the "digital" environment. 


\section{Summary}

The Internet communication tools, including social media marketing tools, are entering the market in growing number of areas of activities of entities (Evans, 2006). The Polish Marshal Offices performing their activities in health promotion and education should take up the challenge to adjust to current requirements and expectations of different social groups. A large target group of health promotion campaigns conducted by the Polish Marshal Offices requires to adapt to modern trends of virtual communication. For modern audiences, flexibility and availability of virtual information are very important. It is caused by a shift from traditional media like television, radio, and newspapers to online media (Clarke, 2014).

The change in technology should also revolutionize the functioning of the offices operating in the healthcare market, which wants to get to the "digital" audience with their health-related transfers. These institutions, at various levels of their activities, may make profits from modern communication technologies if only they follow a new communication trend. It has been postulated to pay more attention by Polish Marshal Offices to social media marketing and social media tools in its actions in the field of health promotion in order to improve the efficiency in communication with the "digital" environment.

\section{References}

Andreasen, A. R. (2002). Marketing social marketing in the social change marketplace. Journal of Public Policy \& Marketing, 21(1), 3-13.

Clarke, R. (2014). The prospects for consumer-oriented social media. Organizacja, 47(4), 219-230.

Czupryna, A., Poździoch, S., Ryś, A., \& Włodarczyk, W. C. (2001). Zdrowie publiczne. Kraków: Vesalius.

Dorenda-Zaborowicz, M. (2012). Marketing w social media. Nowe Media, 3, 59-79.

Dryl, T. (2011). Komunikacja marketingowa z wykorzystaniem mediów społecznościowych jako źródło sukcesu. Zeszyty Naukowe Uniwersytetu Ekonomicznego w Poznaniu, 171, 62-71.

Evans, W. D. (2006). How social marketing works in health care. Journal of Health Care Marketing, 332(7551), $1207-1210$.

Gani, A., \& Clemes, M. (2006). Information and communications technology, a non-income influence on economic well being. International Journal of Social Economics, 33, 651-653.

Gordon, M. (2014). Y warte zabiegów. Marketing w praktyce, 2(192), 16-17.

Karski, J. B. (1992). Promocja Zdrowia (wybrane materiaty źródtowe $i$ dokumenty podstawowe). Warszawa: Centrum Metodyczne Doskonalenia Nauczycieli Średniego Szkolnictwa Medycznego.

Kulka, M. (2014). Koszty firmy w social media. Marketing w Praktyce, 2(192), 50-52.

Pabian, A. (Ed.). (2008a). Środki i formy marketingowego oddziaływania na konsumentów. Częstochowa: Wyd. Politechniki Częstochowskiej.

Pabian, A. (2008b). Promocja nowoczesne środki i formy. Warszawa: Difin.

Syrkiewicz-Świtała, M., Holecki, T., Sobczyk, K., Wróblewski, M., \& Lar, K. (2015). Korzystanie z mediów społecznościowych i narzędzi social media marketingu w promocji zdrowia przez polskie gminy. Journal of Public Health, Nursing and Medical Rescue, 1, 59-64.

Syrkiewicz-Świtała, M., Holecki, T., \& Wojtynek, E. (2014). Znaczenie mass mediów w promocji zdrowia. Medycyna Ogólna $i$ Nauki o Zdrowiu, 20(2), 171-176.

Syrkiewicz-Świtała, M., \& Świtała, R. (2012). Social media marketing jako współczesna koncepcja komunikowania się jednostek ochrony zdrowia z otoczeniem. Zeszyty Naukowe Wydziału Zarzadzania Politechniki Czestochowskiej, 5, 86-94.

Syrkiewicz-Świtała, M. (2014). Uwarunkowania procesu rekomendowania usług zdrowotnych przez przedstawicieli pokolenia Y w aspekcie social media marketingu. Marketing i Rynek, 11, 474-482.

Trzeciak, D. (2009). Era social media. Marketing w Praktyce, 12(142), 70-71.

Vilaseca-Requena, J., Torrent-Sellens, J., \& Jimenez-Zarco, A. (2007). ICT use in marketing as innovation success factor: Enhancing cooperation in new product development processes. European Journal of Innovation Management, 10, $270-271$. 